\title{
光通信帯の光周波数標準の現状
}

\author{
大苗 敦 \\ 産総研 計測標準研究部門 (テ305-8563 茨城県つくば市梅園1-1-1つくば中央第3)
}

\section{Optical Frequency Standards at the Telecommunication Region}

\author{
Atsushi ONAE \\ National Metrology Institute of Japan (NMIJ)/AIST, Tsukuba central 3, 1-1-1 Umezono, Tsukuba, Ibaraki 305-8563
}

(Received October 23, 2006)

\begin{abstract}
We have developed accurate optical frequency standards based on acetylene absorption lines in the telecom region (C-band) and have measured their optical frequencies using several kinds of optical frequency combs. Based on these results, in 2004 we started optical frequency (wavelength) calibration service for stabilized Cband lasers at National Metrology Institute of Japan (NMIJ). We also have the preliminary results of our experiments in transferring wavelength standards via optical fiber networks.
\end{abstract}

Key Words: Optical frequency standard, Optical frequency measurement, Optical frequency comb, Acetylene stabilized laser, Telecom wavelength calibration service

1.はじめに

通信容量の増加に伴い波長分割多重(WDM) 通信方式な どが導入され波長 $1.55 \mu \mathrm{m}$ の光通信带に扔ける波長管理, 光周波数管理のニーズが年々大きくなってきている ${ }^{11}$ 。測 定現場の空気の屈折率の影響を受ける精密長さ計測の場 合と違い, ファイバ中の光に限定される通信带分野で は,「波長」より不確かさの小さい形で議論できる「光周波 数」が適している，実際，WDMのチャンネルの枠組みを 規定するITU-Tのグリッド2)も使波数ベースで定義されて いる.

以前, 光通信带での高精度な波長測定は, 波長 $633 \mathrm{~nm}$ の可視領域の波長標準である, ヨウ素安定化He-Ne レー ザーに基づく大型干渉計により行われてきた3)。ところが 近年, 各種の光周波数コム技術が確立され, 波長比較で はなく, 光ビート計測による光周波数測定が行われるよ うになった. 光周波数測定では, 波長測定の場合に問題 になる回折や屈折率の効果による不確かさの原因を排除 できるので，より不確かさの小さい測定が可能になる. また，アセチレン分子の振動回転遷移の飽和吸収をべー スにした安定化レーザー標準器の研究・開発が進しだこ とを受けて,メートル条約の枠組みの中の組織であり, 波長標準の設定に責任をもつ長さ諮問委員会において，1 $\mathrm{m}$ を実現する安定化レーザーのリスト (CIPM勧告值)の中 に，2001年以降，通信帯の標準としてアセチレン安定化 レーザーが採用されるに至った4)。一方, 通信帯の光部品
メーカやシステム設計者からは, 一部の高品位の場合に 限られるものの, 市販の波長計の不確かさ $(5 \sim 6$ 桁程度)を 超えた標準の必要性が聞かれるようになった。こういっ た技術状況と産業界の二ーズを受けて, 産総研では2004 年度末から，アセチレン安定化レーザーを基準とし, 光 周波数コム技術を利用した，今までの波長計とはまった く異なる方式による通信带Cバンド $(1530 \mathrm{~nm} \sim 1565 \mathrm{~nm})$ の 安定化レーザーの光周波数 (波長) 校正の依頼試験を開始し だ1. 不確かさは通常の波長計と比較し1000倍向上され相 対值で $10^{-9}$ となった。このサービスにより, 例えばより正 確に值付けされた安定化レーザーを参照標準として事業 所内校正を行うことで，製品管理などに使用する製造現 場の波長計などをより有効に活用できるようになる.

2003年のレーザー研究31巻7号では「光通信带での光周 波数標準とその応用」として特集が組まれ, アセチレン安 定化レーザー標準器については中川氏の解説がある。こ れは, 波長同調性が良く, $1 \mathrm{MHz}$ 程度の狭い発振線幅の外 部共振器型半導体レーザーを光源とし, 数 $\mathrm{mW}$ 程度のレー ザー光強度を光共振器の利用で100倍程度増強し, この共 振器の内部に配置されたアセチレン分子セルの飽和吸収 信号を観測する分光計である。得られる飽和吸収信号 (1 $\mathrm{MHz}$ 程度の線幅)を利用して電気的なサーボにより外部共 振器レーザーの周波数を安定化させることで標準器とし ている. 安定度がよく不確かさの極めて小さいこの標準 器の開発経緯はその解説を参照して頂くこととし, 本解 説ではその後の急速な光コム技術の進展, 各種の光コム

${ }^{\dagger 1}$ http://unit.aist.go.jp/genadm/legal/kitei/iraishiken.html\#1 
によりアセチレン安定化レーザーの周波数計測が行われ た様子，その結果を受けて国際標準としてのアセチレン 安定化レーザーの不確かさが改善されていった経緯，そ のような展開を受けて産総研において開始された通信带 における光周波数(波長)の標準供給の概要などについて紹 介する。

\section{2. アセチレン安定化レーザーの周波数計測}

モード同期Ti:Sapphierレーザーからの超短光パルスは， 光周波数軸上で考えると等間隔に並んだ多数のモードが 同じ位相で発振しており，その姿が櫛の歯に似ているこ とから光周波数コム $(\mathrm{comb})$ と呼ばれる.この光コムの $n$ 番 目のモードの光周波数 $f(n)$ は,

$$
f(n)=n \times f(\text { 繰り返し })+f(\text { オフセット })
$$

と表すことができ, パルスの繰り返し周波数， $f($ 繰り返 し)とオフセット周波数, $f$ (オフセット)の 2 オのパラメー 夕を制御することで光周波数の“ものさし”として利用でき る. (詳しくは本特集, 杉山氏の解説を参照). この光コム のスペクトル(ものさし)は，波長範囲でおよそ500 nm か ら1100 nmの広い範囲をカバーするものの，残念ながら通 信帯には届いていない。そこでアセチレン安定化レー ザーの光周波数計測を行うためには工夫が必要であり, いくつかの方法がある。まず第1はアセチレン安定化レー ザーの光を増幅し，非線形光学結晶を使いSHG光を発生 させ，2倍の周波数(半分の波長)の光をこの光コムで測定 する方法である。

Fig. 1は産総研で行われたアセチレン安定化レーザーの 周波数計測の実験装置を示す5).モード同期Ti:Sapphier レーザーは，繰り返し周波数とオフセット周波数が制御 され，光周波数の絶対值を与える光の“ものさし”を実現し ている.周波数を制御したり計測したりする場合のシン セサイザや周波数カウンターはすべて産総研の原子時計 (水素メーザー)からの参照信号を外部基準として使用して いる。“ものさしの目”に対応するパルスの繰り返し周波数 (周波数軸でのモード間隔) は792 MHzである.一方，アセ チレン安定化レーザーからの出力 (波長1542 nm の通信帯) はエルビウム添加ファイバ増幅器 (EDFA)により $200 \mathrm{~mW}$ まで増幅され, リチウムナイオベート分極反転結晶 (PPLN)により $135 \mu \mathrm{W}$ のSHG光 (波長 $771 \mathrm{~nm}$ ) が発生させ られる.この光は分岐比50\%：50\%のファイバカプラー

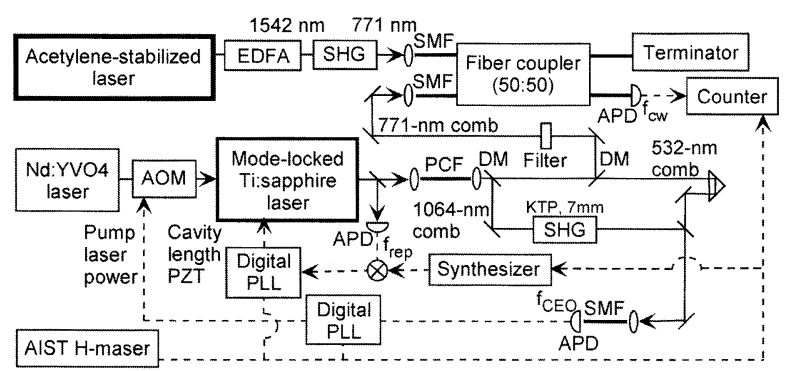

Fig. 1 Schematic diagram of the experimental setup.
により光コムと合波される，安定化レーザーのSHG光約 $20 \mu \mathrm{W}$ は光コムの1つのモード成分 (約 $35 \mathrm{nW}$ ) と高速光検 出器 (APD) に入射され光ビート信号が検出される。この 測定により産総研のアセチレン安定化レーザー (アイソ トープのアセチレン ${ }^{13} \mathrm{C}_{2} \mathrm{H}_{2}, v_{1}+v_{3}$ 振動モード, $\mathrm{P}(16)$ 回 転線)の光周波数の值は,

\section{$f=194369569383.6(1.3) \mathrm{kHz}$}

と求まった。ここで()で囲まれた最後の数字 $1.3 \mathrm{kHz}$ はア セチレン安定化レーザーの再現性で決まる測定の不確か さである. 光コムも含めて光周波数計測の不確かさは十 分に小さく無視できる. Fig. 2は以前の測定も含め, 今回 の測定結果をまとめたものである．1996年の測定6)では， まだ光周波数測定の不確かさが大きな割合を占めてい た. 2001年の測定7)では, 近赤外領域(波長778 nm)の仲介 標準器が利用されたが, その周波数計測は光コムを利用 したもので不確かさは充分に小さかったが，仲介標準器 とアセチレン安定化レーザーの再現性が不確かさを決め ていた. (31巻7号，433ページ) 今回の測定はゲート時間1 秒の周波数カウンターで行われたが，得られた時系列 データからはこの安定化レーザーの安定度の評価も行え る.ゲート時間切1秒から1000秒までの間で, 安定度の目 安となるアラン偏差 $\sigma_{y}(\tau)$ は,

$$
\sigma_{y}(\tau)=1.2 \times 10^{-11} / \tau^{1 / 2}
$$

と表せることが明らかになった。 1000 秒で $4 \times 10^{-13}$ ，約 200 $\mathrm{THz}$ の光周波数に対して $80 \mathrm{~Hz}$ 程度の安定度となる.

産総研のこの測定のあと, 英国とカナダの標準研 (National Physical Laboratory (NPL) と National Research Council(NRC)) からも光コムを使って, アセチレンの飽和 吸収に安定化したレーザーの周波数測定結果が発表され たが8,9)，3者はお互いの測定不確かさ(安定化レーザーの 再現性)の範囲でよく一致していた。これを受けて, 2003 年，パリの国際度量衡局で行われた長さ諮問委員会傘下 の安定化レーザーのリストを検討する作業部会におい て，アセチレン安定化レーザーの不確かさとして $10 \mathrm{kHz}$ 採択された4)．2001年の同様の会議でアセチレン安定化 レーザーが初めてこのリストに承認されたときの不確か さが $0.1 \mathrm{MHz}$ であったことを思い出すと，たった2年間で 10倍向上したことになる，その後，光コム技術を利用し

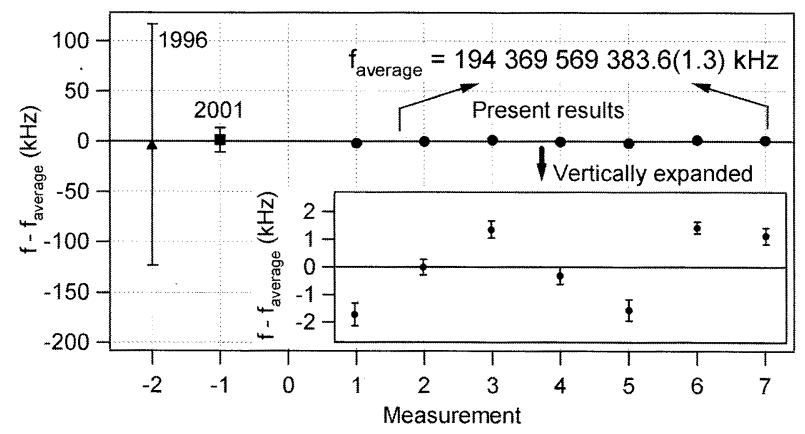

Fig. 2 Absolute frequency and reproducibility of the acetylene stabilized laser. 
たアセチレン安定化レーザーの特性, 再現性の研究が進 み，最新のリストを作成した 2005 年の同じ会議では，ア セチレン安定化レーザーについて, 方式・レーザー出 力・アセチレン封入圧力・信号を得るためレーザー周波 数にかける変調の大きさなどに関して所定の条件を満足 すれば，再現性による不確かさは $5 \mathrm{kHz}$ とできることが承 認された。また，この会議では，アセチレンのP (16) 回転 線以外の振動回転遷移についてもほぼ同様の不確かさで 周波数標準として使用できることが確認され承認されて いる.

産総研ではこのほかにも通信帯の光周波数計測の実験 を行ってきた。第2の工夫の方法は，モード同期 Ti: Sapphierレーザーからの光コムが，スペクトルとして500 $\mathrm{nm}(600 \mathrm{THz})$ から $1100 \mathrm{~nm}(270 \mathrm{THz})$ の広い範囲をカバー し，その帯域の中に通信帯のキャリアの光周波数約 200 THzを含んでしまっていることを利用するものだ. 非線形 光学結晶を用いて光コムの $800 \mathrm{~nm}(375 \mathrm{THz})$ の成分とアセ チレン安定化レーザー $(195 \mathrm{THz})$ との和周波数光 (SFG: 570 $\mathrm{THz}$ )を発生させ, もとの光コムの527 nm (570 THz)の成 分と干渉させることで光ビート信号を検出し, アセチレ ン安定化レーザーの周波数を測定するものである. $2 つ の$ 光コムの差をとることになるので, 式(1)の光コムの $f($ オ フセット)がキャンセルされ，その制御が必要ないこの方 式は長時間の測定にも適しており, アセチレン安定化 レーザーの10,000秒で安定度を初めて評価できた。詳細は 文献を参考にされたい10)。この他の方法として，光の“も のさし”自身を通信帯の領域で作れば測定システムはいっ そう簡単になる。これが第3の方法である。高非線形ファ イバを利用して通信帯で発振するモード同期ファイバ レーザーをベースにした広帯域光コムが開発され，波長 $1000 \mathrm{~nm}$ 以下から $2000 \mathrm{~nm}$ 以上にわたる1オクターブ以上の スペクトル範囲がカバーされるようになった ${ }^{11,12)}$.ファイ バレーザーの光コムの周波数計測システムは小型で安定 性がよく非常に信頼性が高い. 最近, 1週間以上にわたる 連続測定が行われ，アセチレン安定化レーザーの長期安 定性の評価が行われたと同時に，このファイバ光コム． システムの信頼性の高さが実証された12).

\section{3. 産総研における光通信帯の光周波数校正システム}

この章では, アセチレン安定化レーザーと電気光学効 果を利用したもうひとつのタイプの光コムの組み合わせ による光周波数計測システムを紹介する. 通信帯の光周 波数 (波長)の校正業務で通常要求される不確かさは, 最高 のものでも $200 \mathrm{kHz}$ (相対不確かさ $10^{-9}$ ) 程度である. その 場合，前節で述べたような1オクターブ以上のスペクトル を持ち, 絶対周波数が原子時計からの参照信号で校正さ れた光コムを用いなくても，安定化レーザー(再現性 10 $\mathrm{kHz} \sim 100 \mathrm{kHz})$ と, 要求される通信帯のバンドをカバーす る光コムの組み合わせで光周波数を測定し, 被測定対象 を校正することができる. 特に, 電気光学効果を利用す る光コム13)では, 入力した周波数の基準光に対して光コ ムを駆動するマイクロ波周波数の間隔でサイドバンドを
たてるもので, 光の“ものさし”を構成するために周波数に 関するサーボを必要としないためにシステムとして非常 に簡単にでき，信頼性が高いことが魅力である.

Fig. 3に測定の原理を示す．被測定対象 (device under test; DUT)の周波数值によっては，ちょうど光コムのモードと 重なってしまい光ビート信号の周波数がほとんどゼロに なり測定しにくい場合があるので, 光コムの“ものさし”を 参照するバッファレーザーを導入している，この図から 明らかなように被測定レーザー(DUT) の周波数 $f(x)$ は次の ように表される。

$$
\begin{array}{r}
f(x)=f\left(\mathrm{C}_{2} \mathrm{H}_{2}\right)+N \times f(\mathrm{MW}) \\
+f(\text { beat } 1)+f(\text { beat } 2)
\end{array}
$$

ここで, $f\left(\mathrm{C}_{2} \mathrm{H}_{2}\right)$ は基準となるアセチレン安定化レーザー の周波数值, Nは光コムのものさしで何番目のサイドバン ドかを表す整数で光コムの次数と呼ばれる. $f(\mathrm{MW})$ は電 気光学変調器を駆動しているマイクロ波の周波数(例えば 今回の実験では $6.25 \mathrm{GHz})$ である.このマイクロ波の周波 数は, 市販の波長計の不確かさ(例えば $200 \mathrm{MHz}$ )に比べて 充分に大きいので, 被測定対象の周波数をあらかじめ波 長計で測定することで, 次数 $N$ を間違いなく決定すること ができる. $f$ (beat1) は $N$ 次の光コムの成分とバッファレー ザーとのビート信号の周波数, $f$ (beat 2$)$ はバッファレー ザーと被測定レーザーのビート信号の周波数でいずれも 測定されるものである。これにより電気光学变調器のつ くる光コムのスペクトルの範囲であれば任意の周波数を もつ被測定レーザーの周波数を精度よく測定することが できる。この場合の不確かさは主に基準としているアセ チレン安定化レーザーの周波数再現性による．レーザー 間のビート周波数の符号については，2つのレーザー周波 数の大小関係で符号 + , -が生じるが，これはバッファ レーザーの発振周波数をわずかに上下にずらしたときの ビート信号の周波数の増減の方向で区別することができ る. 式(2)のビート周波数の前の符号は, Fig. 3の状況に対 応している。

このシステムを評価するために市販の安定化レーザー を被測定レーザーとして実験を行った。なお，この実験 で使用するアセチレン安定化レーザーは, 電通大と産総

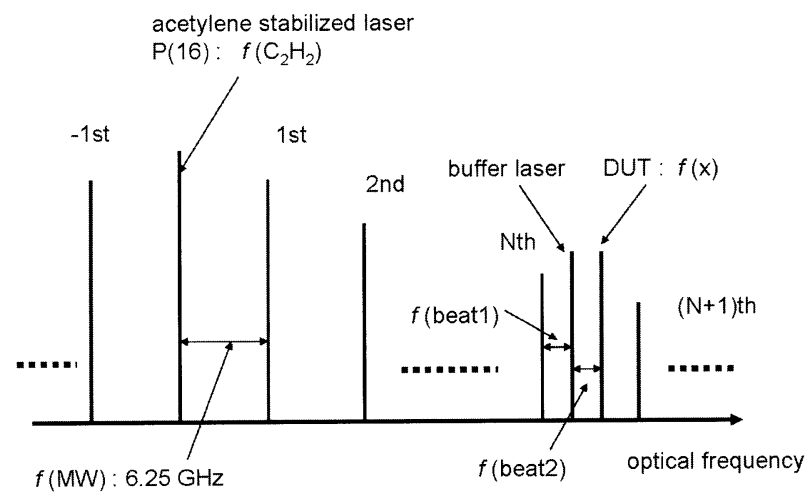

Fig. 3 Principle of frequency measurement using an acetylene stabilized laser and an optical frequency comb. 
研での研究成果をもとにネオアーク(株)が開発した市販品 （型番：C2H2LDS-1540)である。また，電気光学効果を用 いる光周波数コムは，オプトコム株)の市販品(型番：BKSM625C)である．Fig.4に測定系を示すＰP(16) 回転線に安 定化されたアセチレン安定化レーザーの出力はエルビウ ム添加ファイバ増幅器 (EDFA)をとおして光コム (OFCG) に入力される。これにより通信帯Cバンド領域で光の“も のさし”が発生する。一方，バッファレーザーとして波長 可変な外部共振器型レーザーが用意され，この出力光は 同様にEDFAで出力を十分なレベルに調整されたのち2つ の経路に分けられる，ひとつは先ほどの光の“ものさし”と 検出器で混合され，光ビート信号が検出される。もう一 方は，校正されるべき被測定レーザーとやはり混合さ れ，そのレーザーとの光ビート信号が検出される。 それ ぞれのビート信号の周波数は2つのカウンターで同じゲー トタイミングで測定される $(f($ beat 1$), f($ beat 2$))$. 今回の模 擬校正において使用された被測定レーザーは横河電機 製，HCN安定化レーザー(型番：3290S-04)である。この 製品は安定化の基準として線幅の狭い(約 $1 \mathrm{MHz}$ )飽和吸収 でなく通常の線形吸収(ドプラー幅で約 $500 \mathrm{MHz}$ )を利用し ているので，我々の安定化レーザーよりも安定度や不確 かさでは劣るが，コンパクトでロバスト，スイッチを入 れるだけで十分な安定度の基準光を発生できる非常に優 れた市販品である．5時間程度の連続測定の結果をFig. 5に 示す。この模擬校正で使われたレーザーについては中心 周波数の公称值からたつた数百 $\mathrm{kHz}$ 程度の偏差があるだけ であり，仕様にある波長確度 $10 \mathrm{MHz}$ は充分に満たされて いることが確認された。また同様に数百 $\mathrm{kHz}$ 程度のばらつ きが見られるが，被測定レーザーの安定度によるもので ある。このばらつきが我々の周波数計測システムによる ものでないことを示すために，もう1台のアセチレン安定 化レーザー標準器を準備し，基準とは別の遷移P (18)に安 定化してこれをDUTに見立てて同様に実験を行った結果 も Fig. 5の中に示した．值については重ならないように0.3 MHzほど低くずらして表示している。ばらつきが非常に 小さく，この図ではほぼ太い線のようにしか見えない が，これがシステムノイズであり $1 \mathrm{kHz}$ 程度の大きさであ る.このようなデー夕(10秒間隔で分解能 $1 \mathrm{kHz}$ ，絶対周波 数の不確かさ $100 \mathrm{kHz}$ ) は市販の高精度波長計では決して得

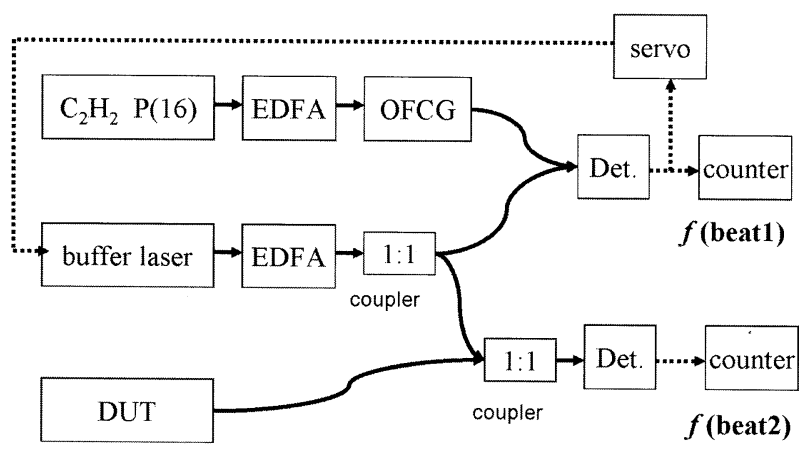

Fig. 4 Experimental setup for frequency measurement of the DUT: EDFA, erbium doped fiber amplifier; OFCG, optical frequency comb generator; Det., detecotors.

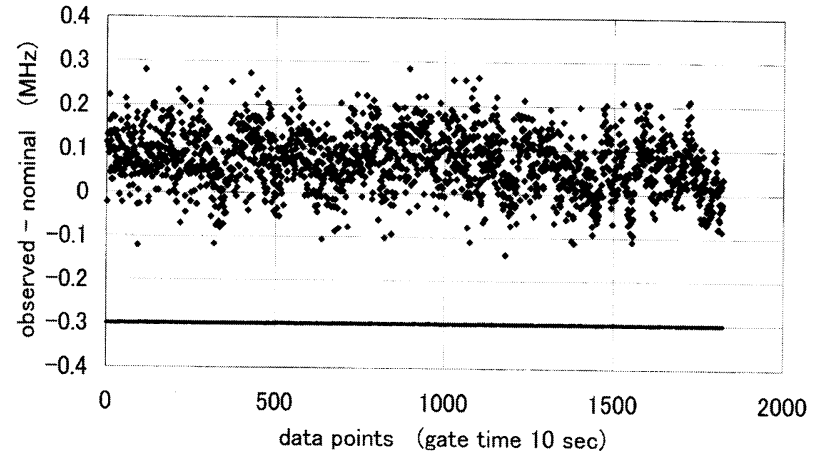

Fig. 5 Results of frequency measurements at the telecom $\mathrm{C}$-band region. The upper trace shows results of frequency measurement of the DUT, while the lower trace (a thick line on $-0.3 \mathrm{MHz}$ ) shows the system noise.

られないものであることを強調しておきたい.

\section{4. 通信帯光周波数の標準供給 (現状と将来の夢)}

産総研では，3章で説明した光周波数校正システムを 使って2004年度末より，通信帯Cバンド(波長 $1530 \mathrm{~nm}$ $1565 \mathrm{~nm})$ における光周波数の標準供給を開始した。不確か さは現在基準として使用している市販のアセチレン安定 化レーザーの再現性 $(100 \mathrm{kHz})$ で決まっている，前節で説 明した技術的な根拠に加えて，標準供給に必要な品質シ ステムを立ち上げ，依頼試験としての校正証明書が発行 できるようになった することをより明確に示すために，海外の研究所の研究 者によるピアレビューを受け，製品評価技術基盤機構 (NITE)による試験所認定ASNITE-NMIを取得した。現 在, 国際相互承認 (MRA) の枠組みに従い校正測定能力 $(\mathrm{CMC})$ 登録の手続きを行っているところである.

この校正サービスでは，校正のためにユーザーに被測 定対象を産総研に持ち込んで頂く必要がある。一方, ファイバを極低損失で伝送するという光通信帯の光の特 長を生かした新しい標準の供給形態も考えられ，その実 用可能性を見極めるための基礎的な研究も行われた。 ま だすべてのユーザーと産総研をファイバで結ぶことは技 術的，制度的にむずかしいが，例えば，通信帯の部品製 造メーカの事業所内において，標準室と実際の製造ライ ンにある波長計をファイバでつなぎ常時波長計を校正す る場合を考えることができる。このためには，数 $\mathrm{km}$ 程度 の伝送路で6桁から7桁の光周波数 (波長) 標準が伝送できる かを確かめる必要がある，新エネルギー・産業技術総合開 発機構 (NEDO)の計量器校正情報システム技術開発 (etrace) プロジェクトにおいて，光ファイバ網を使って電気 信号だけではなく，物理量としての波長や周波数標準を 伝送する方式について, 東北大の中沢研究室と共同で 行った研究のうち, 産総研が分担した波長標準(光周波数 標準)の伝送について以下に紹介する。

実験室においてドラムに巻かれた $10 \mathrm{~km}$ の光ファイバを 使って伝送された基準の光周波数 (波長)がどの程度伝送に 


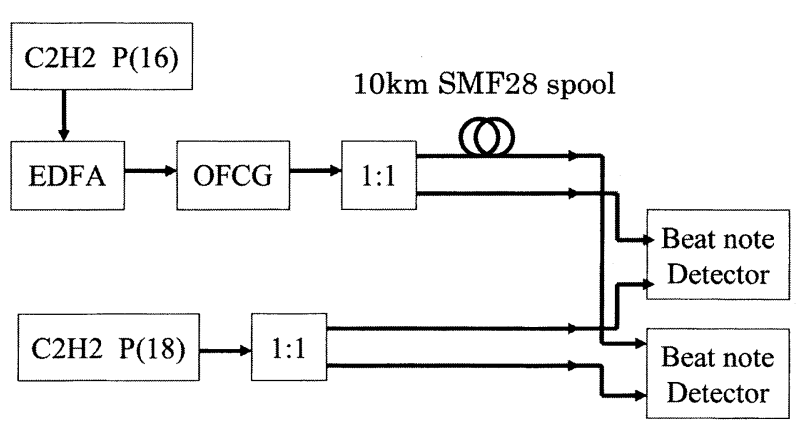

Fig. 6 Experimental setup for the wavelength standard transfer through a $10 \mathrm{~km}$ single mode fiber in a laboratory.

より変化するかを定量的に評価した，実験装置をFig. 6に 示す。これは, 前項でシステムノイズを評価するために 行った実験系を2系統作り，その一方に10 kmのシングル モード光ファイバ経路を挿入して $2 つ の$ 結果を並列に測定 し比較したものである. Fig. 7に観測された光ビート信号 の例を示す. $300 \mathrm{kHz}$ バンド幅のスペクトラム・アナライ ザで観測したところ，信号対雑音比 $(\mathrm{S} / \mathrm{N}) 50 \mathrm{~dB}$ 近くの非常

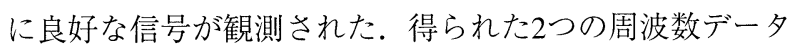
の差を取ることで, 光ファイバによりどの程度光周波数 (波長)がずれるかを非常に精密に評価することができる. 4時間弱の期間にわたる周波数比較のデー夕をFig. 8 に示 す.この結果，伝送されている約 $200 \mathrm{THz}$ の光周波数に対 して，サブHzと極めて小さいことがわかった．温度環境 のよい実験室で数 $10 \mathrm{~km}$ ぼの経路では, ファイバの伸縮 などによる波長標準の伝送前後での周波数の差は, 実用 上まったく問題にならないことがわかった.

次に，産総研と $20 \mathrm{~km}$ ほど離れた場所にある実験室をつ なぐ，外部に敷設(全長のうち9割が架空)された2系統の光 ファイバ経路での安定化レーザーの波長(光周波数)伝送実 験を行った。伝送長は相手側の実験室で折り返し往復 40 kmである. 波長標準としてアセチレン安定化レーザーを 利用した。今回も $40 \mathrm{~km}$ のファイバ伝送路の系統と, 実験 室内での短い伝送路の系統の2系統を比較する形になって

\section{$10 \mathrm{~km}$ comb - P(18) $300 \mathrm{kHz}$ RBW}

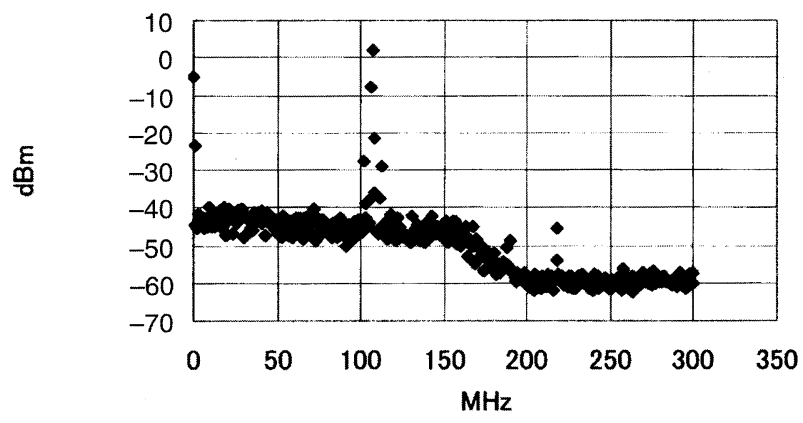

Fig. 7 Observed beat note signal (about $108 \mathrm{MHz}$ ) between a $P(18)$ stabilized laser radiation and the nearest component of the comb, transferred through a $10 \mathrm{~km}$ fiber, by a RF spectrum analyzer. The signal to noise ratio of $50 \mathrm{~dB}$ is confirmed with $300 \mathrm{kHz}$ resolution bandwidth.

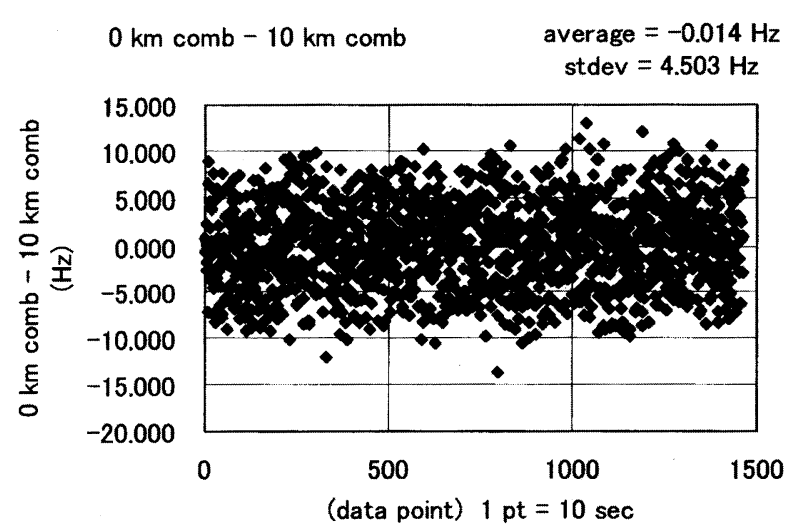

Fig. 8 Comparison between two beat signal frequencies: two beat frequencies between the $\mathrm{P}(18)$ stabilized laser and the nearest component of a comb with a $0 \mathrm{~km}$ delay and $10 \mathrm{~km}$-delay, respectively.

いる．屋外敷設のファイバ $40 \mathrm{~km}$ と室内の短い伝送路での 周波数変化をそれぞれ検出するために参照用としてもと の波長標準を光音響 $(\mathrm{AOM})$ 素子で $80 \mathrm{MHz}$ 途2系統用意した。それぞれにおいて，伝送した光と参照 用の $80 \mathrm{MHz}$ ずらした光の光ビート信号を検出する．得ら

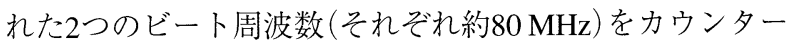
の比測定モードで測定した。ほぼ1日間のデータをFig.9に 示す。この図で縦軸に“1”とあるのが，光周波数のずれが ない場合である，比が1より大きいのは $40 \mathrm{~km}$ の伝送の結 果，光周波数が高くなっていることを示している．夜遅 くからあくる日の夜までのデータである. 夜中のうちは1 よりも少し大きい值になっている。これは光ファイバが 夜間の温度低下に伴い徐々に縮んでいるために起こる現 象であると解釈できる. 日の出と同時に, 気温が急速に 上昇しそれに合わせて周波数が急速に下がる(1から大き く減少する)ことが見て取れる。また，夕方には日没に伴 う気温の下降の影響が出ている。得られた生データには スパイク状に1を大きく下回るデータがいくつか含まれて いたが，ここでは周波数変動のうち比較的ゆっくりとし た成分と気温变化との対応を見るために，それらのスパ

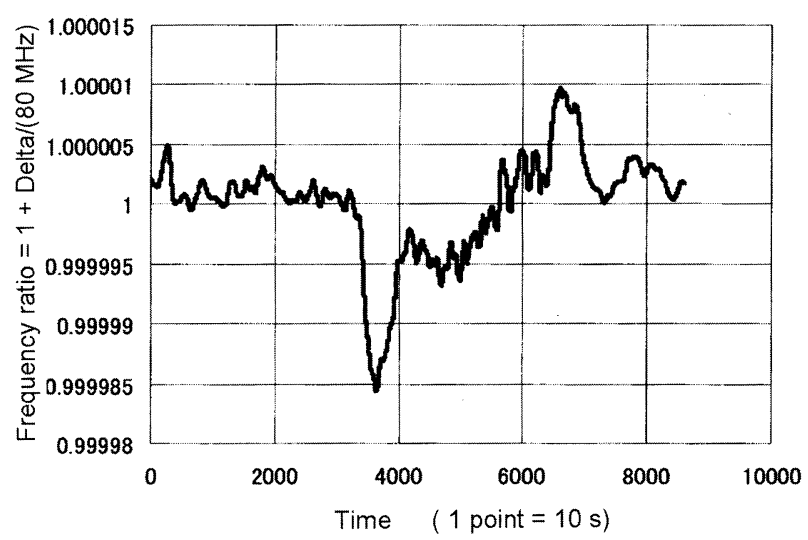

Fig. 9 Frequency ratio of two beat note signals with $0 \mathrm{~km}$ and $40 \mathrm{~km}$ fiber transfer, respectively. Data point below (above) "ratio 1" means that the frequency has been shifted lower (higher) after $40 \mathrm{~km}$ fiber transfer. 
イク的なデータを抜き去り移動平均により細かい構造を ならしたあとのデー夕を用いている。図からわかるよう に周波数比の偏差は， $3 \times 10^{-5}$ 程度である．測定周波数 80

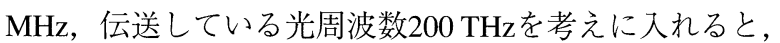
光周波数(波長)に換算して $10^{-10}$ (10桁)の相対不確かさには 充分対応できることがわかる。この程度であれば光ファ イバの経路に対して環境の温度変化などの補正サーボを かけなくても標準伝送時の不確かさを確保できそうであ ることがわかった。より不確かさの小さい伝送のために は文献14)にあるようなファイバ長についての制御が必要 になる．時おり現れたスパイク状信号の原因はまだ特定 できていない。この現象も含めてシステム全体での光周 波数 (波長) 伝送の不確かさ評価を行うことは今後の課題で ある。

\section{5. おわりに}

産総研計測標準研究部門で行われている光通信帯にお ける光周波数計測の実験と, その成果を受けて最近開始 された通信帯における光周波数 (波長)の標準供給サービス について紹介した。また，実際に敷設されているファイ バ経路を利用した光周波数(波長)標準の伝送についての予 備的な実験結果も紹介した。すでに，通信帯の領域で1オ クターブのスペクトル広がりをもつモード同期ファイバ レーザーが実現され，Cs原子標準の不確かさと同じレ心゙ ルまで光周波数を設定できるようになってきている。し かし，分光学やレーザー制御技術の観点から，またコン パクトな波長標準の製品化を目指す意味から，アセチレ ンなどに安定化された通信帯の安定化レーザーの諸性能 の改良, 高度化は今後も興味ある課題として研究されて いくだろう。分子の飽和吸収の信号強度をもとに計算さ れる安定度の理論限界はまだずっと先にあり15)，現状の 10倍以上よくなるはず，との指摘もある。このあたりの 事情を突き詰めて究極の性能を達成できるようにしてお けば，もし分子の並進運動制御技術が原子での場合のよ うに成熟してきたとき，分子の振動回転遷移に基づく近 赤外遷移は非常に魅力的な周波数標準の候補になる可能 性がある16). 光源としてもファイバレーザーなど線幅の 狭いレーザーで同調特性の良好な製品も出回るように なってきている。一方，光ファイバ網を利用して波長や 周波数などのより高精度な標準伝送の可能性をさぐる研 究もますます活発になるものと思われる．光通信帯での
光周波数標準の研究は, 今後も活発に続けられ, 多くの 興味深い成果が得られるだろう。

\section{謝 辞}

共同研究者である産総研の松本弘一氏，美濃島 薰氏， 洪 鋒雷氏，稲場 肇氏，電通大の中川賢一氏に深く感謝い たします。アセチレン安定化レーザーの製品化について ネオアーク(株)の李 容哲氏，波多野智氏に感謝いたしま す.

本解説で紹介した内容のうち，モード同期レーザーの 光コムでの周波数計測については，JSTの科学技術振興調 整費「ブロードバンド光シンセサイザの開発」の成果であ り，標準供給システムとファイバによる波長標準の伝送 に関してはNEDOの「e-trace」プロジェクトの成果である。

\section{参考文献}

1）大苗 敦，池上 健，中川 賢一，古賀 正文，手島 光啓：電気 学会論文誌 C119（1999） 765.

2) ITU-T Recommendation G.692: Optical interfaces for multichannel systems with optical amplifiers (1998).

3) J. Ishikawa and H. Watanabe: IEEE Trans. Instrum. Measur. IM42 (1993) 423.

4) T. J. Quinn: Metrologia 40 (2003) 103; R. Felder: Metrologia 42 (2005) 323.

5) F. -L. Hong, A. Onae, J. Jiang, R. Guo, H. Inaba, K. Minoshima, T. R. Schibli, and H. Matsumoto: Opt. Lett. 28 (2003) 2324.

6) K. Nakagawa, M. de Labachelerie, Y. Awaji, and M. Kourogi: J. Opt. Soc. Am. B13 (1996) 2708.

7) A. Onae, K. Okumura, K. Sugiyama, F. -L. Hong, H. Matsumoto, K. Nakagawa, R. Felder, and O. Acef: Proceedings of the 6th Symposium on Frequency Standards and Metrology, 2001, ed. P. Gill, World Scientific, (2002) p. 445.

8) C. S. Edwards, H. S. Margolis, G. P. Barwood, S. N. Lea, P. Gill, G. Huang, and W. R. C. Rowley: Opt. Lett. 29 (2004) 566.

9) A. Czajkowski, J. E. Bernard, A. A. Madej, and R. S. Windeler: Appl. Phys. B79 (2004) 45.

10) J. Jiang, A. Onae, H. Matsumoto, and F. -L. Hong: Opt. Express 13 (2005) 1958.

11) T. R. Schibli, K. Minoshima, F.-L. Hong, H. Inaba, A. Onae, H. Matsumoto, I. Hartl, and M. E. Fermann: Opt. Lett. 29 (2004) 2467.

12) H. Inaba, Y. Daimon, F.-L. Hong, A. Onae, K. Minoshima, S. R. Thomas, H. Matsumoto, M. Hirano, T. Okuno, M. Onishi, and M. Nakazawa: Opt. Express 14 (2006) 5223.

13) K. Imai, M. Kourogi, and M. Ohtsu: IEEE J. Quantum Electron. QE34 (1998) 54.

14) M. Musha, Y. Sato, K. Nakagawa, K. Ueda, A. Ueda, and M. Ishiguro: Appl. Phys. B82 (2006) 555.

15) C. Ishibashi, J. Ye, and J. L. Hall: Proceedings of SPIE 4634 (2002) 58.

16) M. Kajita: Phys. Rev. A74 (2006) 035403. 